\title{
Role Of Women In Development Of Pakistan: A Case Study of Women Participation in Labour Force in Pakistan
}

\author{
Sadaf Mustafa \\ Department of Commerce \\ University of Karachi \\ M. Sadiq Ali Khan \\ Department of Computer Science \\ University of Karachi \\ Ammad Zafar \\ Department of Public Administration \\ University of Karachi
}

\begin{abstract}
This paper highlights the "role of women in development of Pakistan". Women participation is very vital for the prosperity of economy of Pakistan. Pakistan is a male dominated society despite the fact that its major population consists of women. In Pakistan the women face lots of obstacles when they want to utilize their skills for the growth and development of the country such as religious, political, social and environmental, although education, health and nutrition are the main issues on the top of list of severe problems. The Pakistani women are neglected and targeted by the customs and values of their families and relationships. The drastic fact is that majority of women of Pakistan live in rural areas as compared to the urban areas where they are treated as animals. However, it is also a fact that currently lots of metropolitan women in all provinces perform marvelous activities for the progress of Pakistan. The study reveals women play dynamic role in boosting economy. We cannot ignore the astonishing performance of women in building developed countries.
\end{abstract}

Keywords: Women Participation, Economic Development, Islamic Views, Politics.

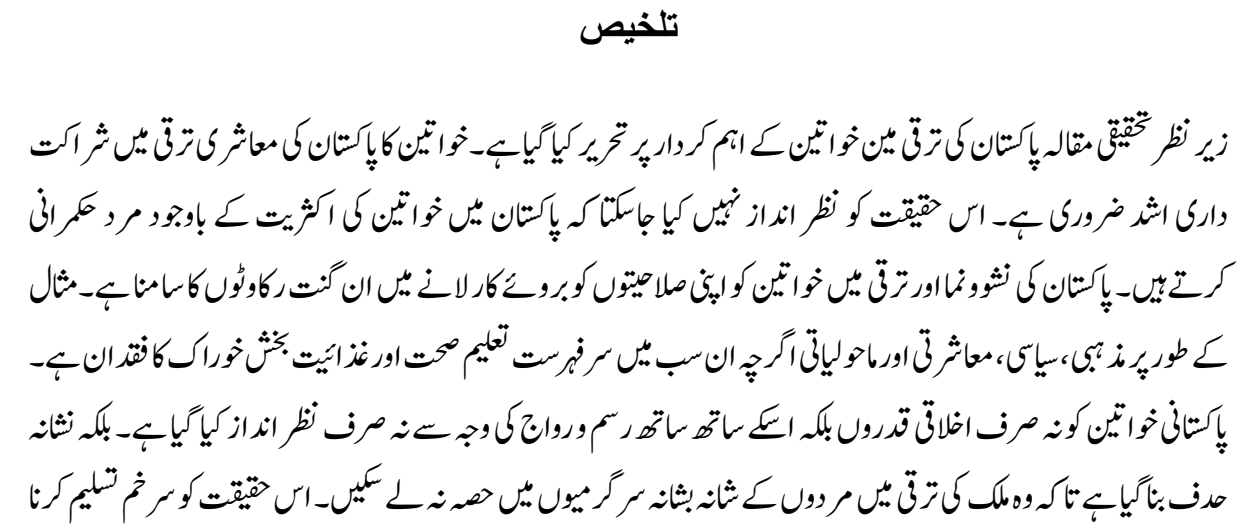




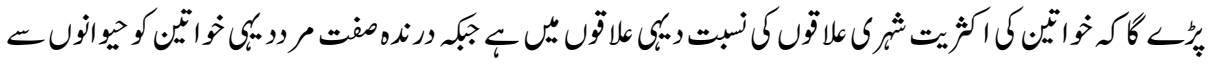

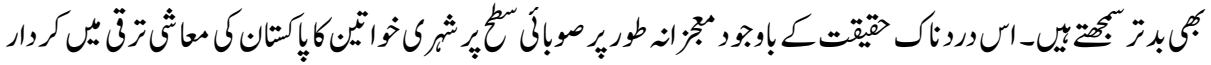

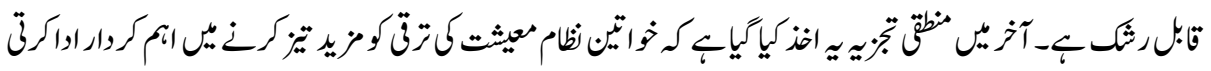

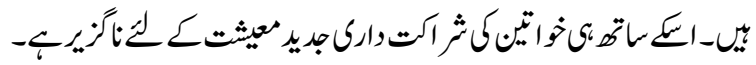

$$
\begin{aligned}
& \text { كليرى الفاط: خواثينكى ثموليت،معاثى ارتقاء، اسلاق نظريات،سياست }
\end{aligned}
$$

\section{Introduction}

Women development is very crucial in the development process of a country whether they are developed or developing countries. History and current statistics revealed that women participation is very remarkable in the war of becoming advanced economies such as United States, China, Turkey, Malaysia, Hong Kong, Thailand, India, United Kingdom, and European countries. Dulfo (2012) clarified that women empowerment and development of a country are straightly associated with each other; in this manner the concerned authorities should maintain equality among men and women in the process of economic development through effective strategic actions and policies.

IMF report (2013) stated that the utilization of skills of women on equal basis with men increased the level of productivity as well as women performed their jobs better than men at managerial level and also increased productivity through excellent decision making. This shows that women have an important role in increasing the level of business activity. World Bank report (2003) also emphasized the importance of working equality of men and women in the following manner:

"There is now a shared understanding with in the developed community that development policies and actions that fail to take gender inequality into account and fail to address disparities between male and females will have limited effectiveness and serious cost implications".

So in this manner there is no doubt to say that investment on women for the purpose of their education, health and safety is very fruitful in economic growth. Women participation in economic activity brings economic prosperity. This paper also emphasizes on the role of Pakistani women in economic development.

Meng (1998) also contributed their research findings about massive participation of women in three industries which are spinning, electronics and garments respectively in South and East Asian countries for instance in Hong Kong, Thailand, Malaysia, Indonesia, India and China. He analyzed that the rapid economic growth of above mentioned South and East Asian countries are due to encouragement of women labour force in their industries which shows that women contribution is vital at all levels. 
Unfortunately, the major part of the population of Pakistani women is victimized by the uncivilized men living in rural areas who have very low mental approach. The Pakistani government and the concerned authorities have adversely failed to avail the opportunities and challenges through the massive part of rural areas agricultural land, minerals, skilled and unskilled cheaper labour (including men and women) etc. The Pakistani government is also incompetent to attract foreign direct investment in all business sectors mainly in manufacturing, service, IT and tourism specifically due to the terrorism and adverse law and order situation and also because of inadequate strategies and policies. Although, in this rapid growing world it is very difficult to share the fact that in Shumali Waziristan, an area of Northern Pakistan the women are not allowed to cast vote in election, even that the women cannot go for shopping for their own necessity and choice as well as if any women take action against these rules she is murdered by the social animal man.

Besides the above mentioned facts, the women of cities play a significant role in the development of economy of Pakistan. The metropolitan citizen women are very efficient and talented to participate the role with men in the progress of the country through availing the opportunities and challenges. Pakistani women are very skillful and performing activities in every field of life such as in IT, research, military, police, aviation industry, teaching and medical science. The Pakistani women also are elected through elections and serving the country as a member of national and provincial assembly.

\section{Literature Review}

As explained above the encouragement of women as well as the participation with men is mandatory in every field of life for the sake and advancement of economy. Ziv, Habayib and Cinamom (2015) also interpreted that now a day's most of the countries are very vigilant about the equal opportunity regarding men and women. In this concern the fundamental step required is to educate women on urgent basis. Queder and Asrar (2011) also focused the significance of schooling of women which is very crucial for the creation of gender equality in the progress of economy. He supported his statement by giving the example of Israel, where the ratio of the literacy of Israeli Arab women has increased rapidly therefore they are well committed in economic flowering. This shows that educating women is necessary not only for women itself but also for overall growth of the country's economy.

Pakistan is a developing country so the government must invest for the education of women and in this connection the prompt strategic actions should be made for the evolution of economy. Fatima (2010) criticized the role of Pakistani government in respect of women education specifically the ground level investment in education in rural areas. She also illustrated the example of Bangladesh, India, Morocco, and specially Pakistan where the position of women education is not satisfactory and fair in all rural areas as compared to urban areas. She also agreed with the above discussion and also 
shared his views regarding the injurious situation of women schooling and learning in Pakistan. According to her the education ratio of women and men was little bit increased in 1991 which were $27 \%$ and $47 \%$ compared to the year 1981 in which the ratio was $16 \%$ and $35 \%$ respectively. Although in rural areas of Pakistan the trend of acquiring education is very low comprising of $7 \%$ of women and $26 \%$ of men.

However according to Grunenfelder (2013) between the periods of $1980-2000$ the ratio of women participation in the progress of Pakistan was very depressed as compared to the other South Asian countries. On the other side the job quota for women is limited which reflected the gender inequality. Even that, in the year 2008 the rate of women employment has increased by $22 \%$ for women and $82 \%$ for men which is not sufficient for the welfare of Pakistan. As it is already discussed above that there is more population of women in Pakistan than men.

The main hurdle which is caused the declining ratio of employment of Pakistani Muslims women is" pardah" and "hijab" specially in Northern areas such as Abbottabad, Battagram, Haripur, Kohistan, Manshera and also in Shumali Waziristan. K. Besio (2006) also shared the valid arguments regarding the difficulties of Muslims women in abovestated areas. Despite the fact in Pakistan Muslims women are very brilliant and also efficiently playing role in every field of life mostly in urban areas. A. Weiss (1984) highlighted the serious strategic actions for the motivation of those Muslim women who want to work within "pardah" in industries and laboratories. Unfortunately, the above mention actions are meaningless because of restrictions imposed by the family members based on the religious and cultural values.

All the above discussion revealed that active participation of women is very compulsory for the development of Pakistan. The meritorious leader of Pakistan Quaid-e-Azam Muhammad Ali Jinnah also focused the importance of women role for a country. Wajiha and Aliya (2014) also focused the women empowerment for the growth of Pakistan. Noman, Muhammad and Mujahid (2013) also discussed that the efficient role played by the women of Pakistan increased the productivity of economy in agricultural, industrial and also in service sectors as well as women assistance in the process of economic development also very favorable and helpful by increasing the level of female education, health and employment. Malik, Choudhry and Faridi (2011) also explored that the women cooperation is very helpful to boost the economy of Pakistan like the other developing countries.

\section{Research Methodology}

This is an explanatory research based on data collected from secondary source. Literature from research journals is added to this research to identify the "role of women in 
economic development of Pakistan" especially participation of women in labour force of Pakistan. This study reviews the literature related to women participation in Agriculture and Politics of the country. It is highlighting the Islamic views about the women empowerment.

\section{Islamic Views of Women Empowerment}

Islam is very comprehensive religion in accordance with every field of life. Islam covered and conveyed the laws about the security and welfare of women as recommended for men. Choudhry, Noosheen and Lodhi (2012) elaborated the well and blooming status of women as defined and determined by Islam. Islam empowered women to get knowledge and expertise.

In this regard the prophet P.B.U.H said:

"Seeking knowledge is a mandate for every Muslim (male and female)".

In Holy Quran Allah declared about the women empowerment in the following manner:

"And (asfor) the believers, both men and women they are friends and protectors of one another: they (all) enjoin the doing of what is right and forbid the doing of what is wrong, and are constant in prayer, and render the purifying dues and pay heed unto God and His messenger" (Al - Taubah 9:71).

Islam is the only religion who gave the venerable rights to the women around 1400 years ago and also provides the concept of equality between men and women and awards the reward to those men who give respect to their mothers, wives, as well as daughters. This concept of giving dignity, respect, equality with men also verified by the following statement of Allah in the Holy Quran:

"For Muslim men and women, for believing men and women, for devout men and women for true men and women who are patient for men and women who humble themselves, for men and women who give in in charity, for men and women who fast, for men and women who guard their chastity, and for men women who engage much in Allah's praise - for them all has Allah prepared forgiveness and great reward" (Al-Ahzab 33:35).

This concept of equal right of duties, responsibilities and honor between men and women also stated by Choudhry, Noosheen and Lodhi which is powered by the following saying:

"They are your garments and you are their garments. (Al-Baqara 2:187)

There is a worldwide misconception regarding Islam that Islam prohibited Muslim women from working and going out for jobs. The fact is that Islam has allowed Muslim 
women to manage and administrate their businesses. Shahida and Iram (2013) also clarified the Islamic conception in respect of Muslim women employment and businesses. They argued with the help of Quran and Hadith and stated that Islam permit the Muslim women to earn but it must base on honesty and fairness. They shared this fact in the following manner by the help of Quran.

"Allah says, and do not covet what Allah has given some of you more than others: The men shall have their due share according to what they have earned and the women shall have their according to what they earned, so pray to Allah for his bounty; most surely Allah has perfect knowledge of everything."

Shahida and Iram explained the different thoughts regarding the above stated verse such as "earn" is explained to perform excellent and positive acts as well as Qatadah (RA) also agreed that earns men "good action" although according to Ibn Abbas earn means to do efforts for financial prosperity. Imam Qurtabi and some other reviewer also verified the views of Ibn Abbas. This concept of earning also proved by the following saying of Jabir Bin Abdullah:

"Jabir bin Abdullah said; my maternal aunt was divorced and she wanted to harvest her date palms. A man rebuked her for going out, so she went to the prophet (SAW) (inquiring about going out during Iddah) and he said: No, go and harvest your date palms, for perhaps you will give charity or do an act of kindness".

Pakistan is a country formed on the name of religion that is Islam. Although, the religion followed in Pakistan i.e. Islam has given equal rights to women to work, to get education and stand beside men still the religion is used for not giving rights to women and treating them badly. The country is in developing stage so in this regard the Government of Pakistan should take immediate strategic actions for the active participation of women as declared by Islam especially in rural areas. The active participation of women in businesses will bring economic prosperity in the country improving the standard of living of the population especially the women and will bring gender equality.

\section{Women Participation in Labour Force of Pakistan}

Women in Pakistani society are playing vital role in the economic development. According to Labour force survey from 2009 to 2011, 2013 to 2015 data is showing increase in participation of women in labour force of Pakistan. 61.04 million labour force was available for work up to 2015. 46.38 million male labour force was available in different areas of work while utilization of women 14.66 million (See Error! Reference source not found. and Figure 1). Despite of fact of poor utilization of Women Labour force results of survey representing a positive trend with the increase annual women 
participation for labour force in Pakistan. This increase in Labour force is directly affecting GDP of Pakistan.

Table: 1

Civilian labour force in Pakistan (Millions)

\begin{tabular}{|l|c|c|c|c|c|c|}
\hline National & 2009 & 2010 & 2011 & 2013 & 2014 & 2015 \\
\hline Year & 53.72 & 54.92 & 57.24 & 59.74 & 60.10 & 61.04 \\
\hline Both Sexes (15+) & 41.91 & 42.44 & 43.95 & 45.98 & 45.65 & 46.38 \\
\hline Males & 11.81 & 12.48 & 13.29 & 13.76 & 14.45 & 14.66 \\
\hline Females & \multicolumn{7}{|l|}{} \\
\hline Rural & 37.30 & 38.17 & 39.70 & 41.23 & 41.14 & 41.95 \\
\hline Both Sexes (15+) & 27.51 & 27.77 & 28.69 & 29.89 & 29.10 & 29.70 \\
\hline Males & 9.79 & 10.40 & 11.01 & 11.34 & 12.04 & 12.25 \\
\hline Females & 16.42 & 16.75 & 17.54 & 18.51 & 18.96 & 19.09 \\
\hline Urban & 14.40 & 14.67 & 15.26 & 16.90 & 16.55 & 16.68 \\
\hline Both Sexes (15+) & 2.02 & 2.08 & 2.28 & 1.61 & 2.41 & 2.41 \\
\hline Males
\end{tabular}

Source: Labor Force Survey Pakistan 2009-11, 2013-15

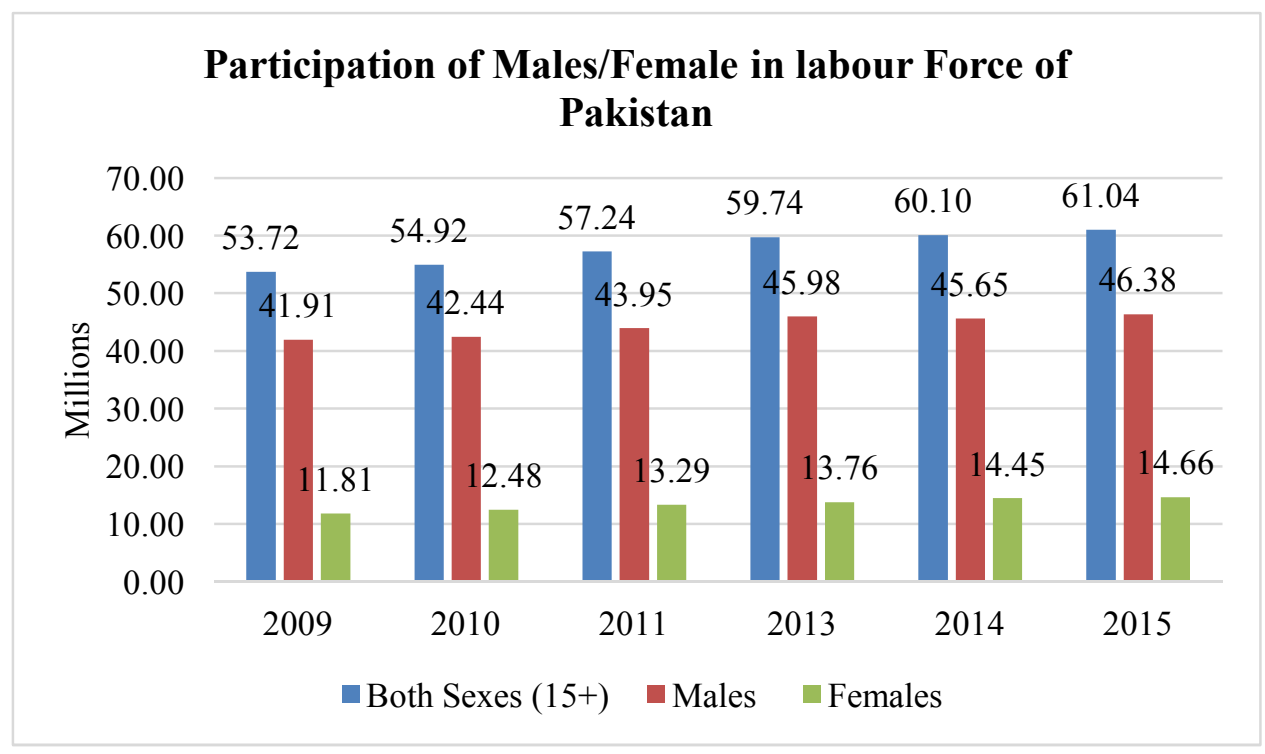

Figure 1 
228 Role of Women in Economic Development of Pakistan: A Case Study of Women Participation in Labour Force in Pakistan

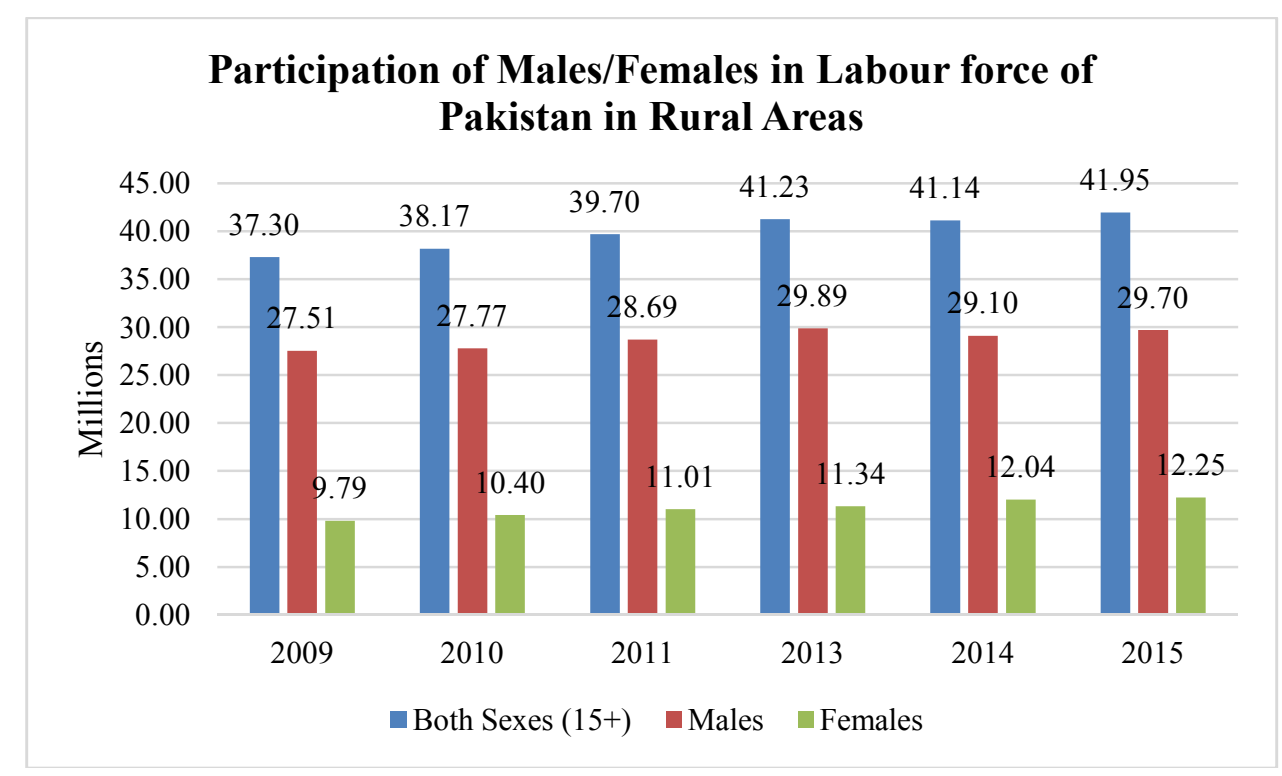

Figure 2

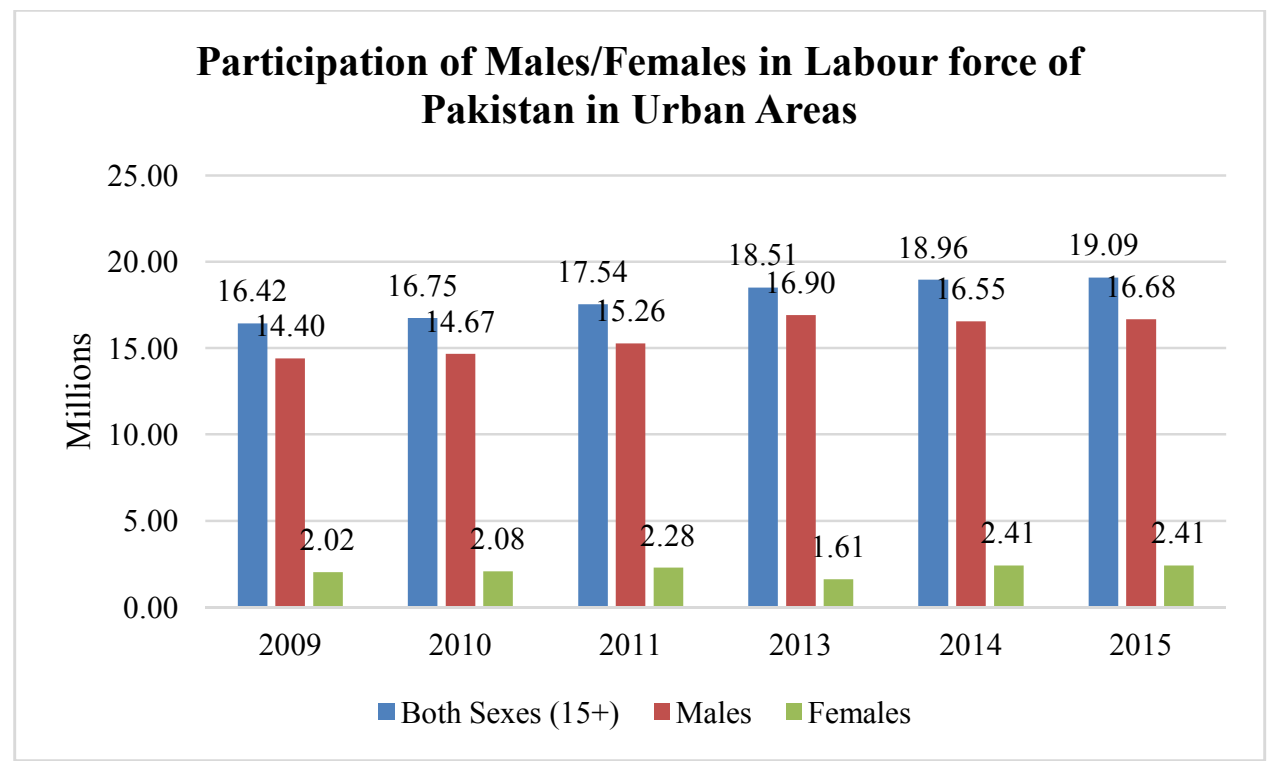

Figure 3

The study reveals in urban areas of Pakistan 19.09 million labour force was participating in work activities. 16.68 million males labour force was engaged in work and 2.41 women were part of work activities. Study found positive growth in labour force for both sexes up to 2015 (See Table 1 and Figure 2). 41.95 million labour force was participating up to 2015 in the rural areas of Pakistan. The women labour force participation is increasing in 
rural areas having more rapid growth with respect to urban areas. 12.25 million women were participating different work activities (See Table 1 and Figure 3) which is a good sign for Pakistan.

\section{Agriculture Industry and Women Participation}

Pakistan is a least developed country (LDC) and its growth is based on agriculture industry. Therefore, Pakistan needs active research and development departments and advance technological tools, techniques and equipment's to compete in the international market to increase the level of export of the furnished and non-furnished products. Pakistan also known as agro -based economy because its major part of national income based on agriculture which is also the main source of creating of employment of men and women for both rural and urban areas. Razia and Ghazala (2011) also contributed their valuable research regarding the impressive participation of women role in agricultural industry which is the main source of national income but unfortunately the extraordinary role of women of rural areas in agricultural industry is hidden at national level. They also highlighted the major problems suffering by agricultural women mainly are health, education, shortcoming of finance and loan facilities, lack of proprietary rights of land, utilization of advanced technological equipment's instead of women labor force, lower wage rate etc. Rashid and Abdullah (2013) stated that in rural areas, Pakistani women participation is remarkable and their contribution is greater than men which is about $79.4 \%$ and $60.8 \%$ respectively. Mir, Ali, Ahmed and Zafar (2009) verified that 50\%of the labor force of Pakistan is contributed by rural women but this is miscalculated and neglected by concerned authorities' surveys and reports. According labour force survey from 2009 to 2011 \& 2013 to 2015, in the year $200945 \%$ of labour force of Pakistan were engaged in Agriculture/Forestry/Hunting and Fishing industry. This situation is also facing by the other various developing countries. $37 \%$ males and $74 \%$ women labour force were participated in the industry. Participation of women in Agriculture/Forestry/Hunting and Fishing industry is more crucial than men. According data agriculture industry is much more dependent women participation. In the labour force survey $73 \%$ of women and $33 \%$ men were engaged in Agriculture/Forestry/Hunting and Fishing industry which $42 \%$ of participation of total labour forces (See Error! Reference source not found.and Figure 4).

Table: 2

Participation of labour force of Pakistan in agriculture/forestry/hunting \& fishing

\begin{tabular}{|l|c|c|c|c|c|c|}
\hline Year & 2009 & 2010 & 2011 & 2013 & 2014 & 2015 \\
\hline Both Sexes (15+) & $45 \%$ & 45 & $\%$ & $44 \%$ & $44 \%$ & $42 \%$ \\
\hline Males & $37 \%$ & $37 \%$ & $36 \%$ & $35 \%$ & $34 \%$ & $33 \%$ \\
\hline Females & $74 \%$ & $75 \%$ & $75 \%$ & $76 \%$ & $74 \%$ & $73 \%$ \\
\hline
\end{tabular}

Source: Labor Force Survey Pakistan 2009-11, 2013-15 


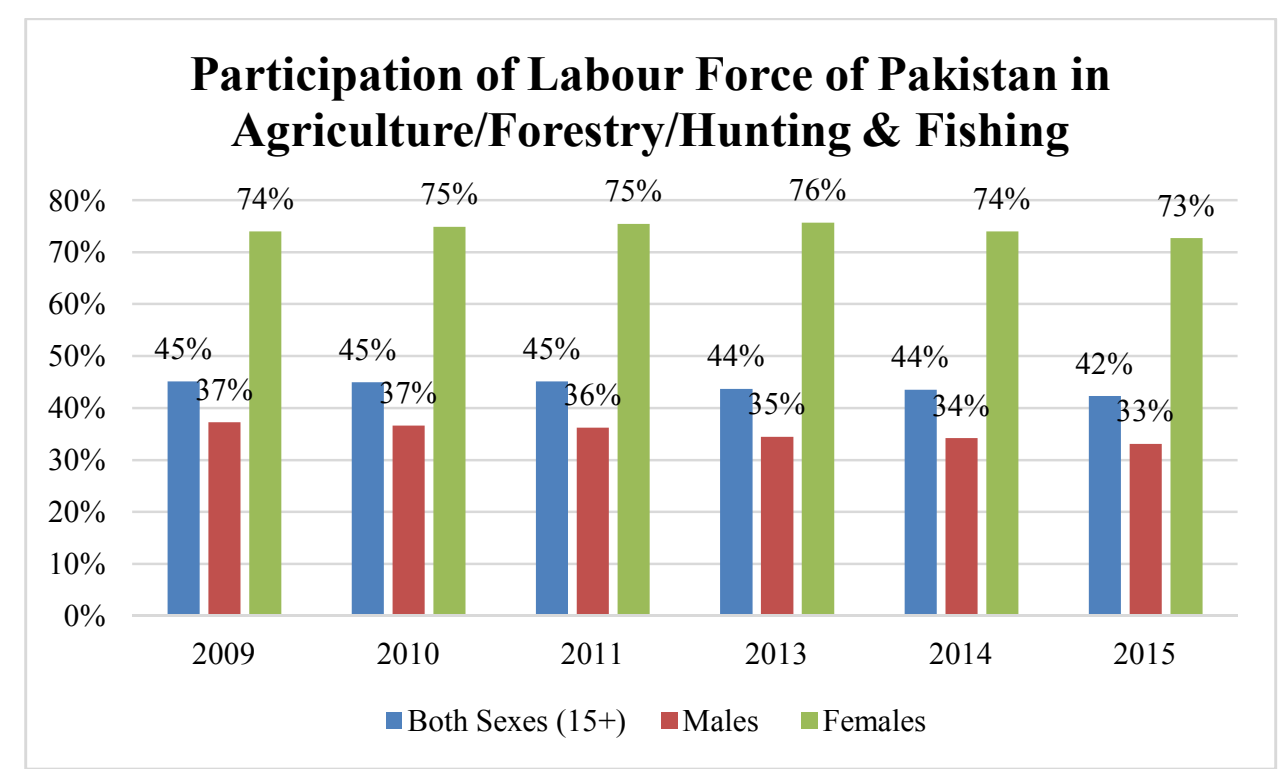

Figure 4

\section{Participation of Pakistani Women in Politics}

It is discussed above that the status of women in Pakistan is not very good and they are not given the equal rights as of men. But Pakistani women surprisingly are playing very active and admirable role in Pakistani politics. Pakistani women politician is very competent to identify and resolve the issues and problems regarding women as well as men in the society.

Pakistani politician women's aim is not only to participate with men in flowering the economy but also work out for the complication, weakness and deficiencies of women living in rural and also in urban areas. Now days the majority of women are also participating in election and elected for the member of provincial as well as national assembly for example Dr. Fehmida Mirza Deputy Speaker of national assembly of Pakistan and Shahla Raza was Deputy Speaker of provincial assembly of Sindh. Prof. Dr. Zakar (2011) also explained the effective and efficient role which is playing by Pakistan politician women for the best democratic government in Pakistan. In this regard the educated, active, sincere, efficient leadership is required to achieve the motive of best democratic governance. The history showed that Pakistani politician women also have knowledge regarding the policy making and legislation as well as planning, organizing and running election campaign. In this connection the formal training should provide to those elected politician women who want to handle the affairs efficiently. 
Following figure also very helpful to analyze and evaluate the member of elected women in Pakistani national assembly election 2013.

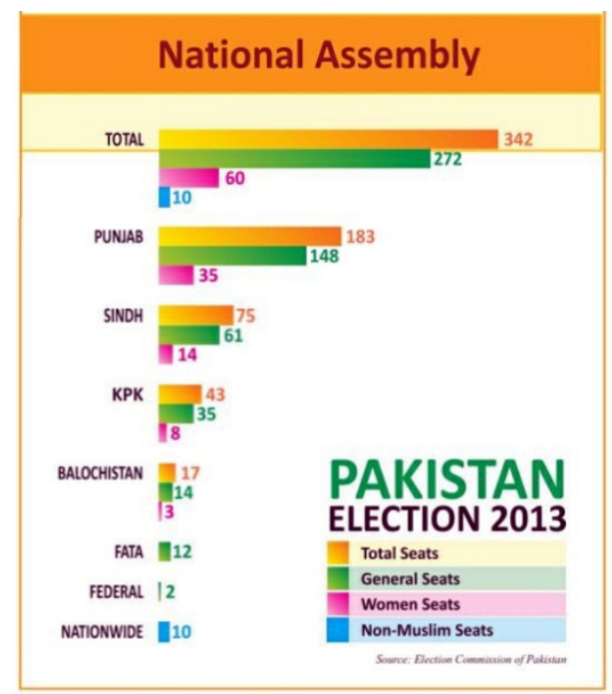

Source: Prof. Dr. Muhammad Zakria Zakar (2011)

The above figure demonstrated the considerable participation of Pakistani politician women in national assembly in 2013. The total seat won by women are 60 which are sub divide in Punjab (35), Sindh (14), KPK (8) Baluchistan (3) and no women members are elected in Fata, because there is huge in equality of men and women in the region. The main reason of the in equality in Fata is uncivilized men who treat their women as slaves. The other main reasons are pardah and hijab, a rule provided by Islam for Muslim Women.

\section{Conclusions}

This research papers explored and analyzed the fact that women participation is very crucial for the development of a country whether they are developed or developing. Another reality is that the Pakistani women are very competent and can achieve difficult task because they are very hard worker. This research papers also highlighted the misconception which is associated with Islamic rules. Islam give equal rights to women as recommended to men. This research paper also focused the difficulties and hurdles which are the barrier in the process of women improvement. Islamic and Pakistan's history demonstrated the achievements of women which are incredible for example Hazrat Khadija, Hazrat Aisha, Madre Millat Fatima Jinnah, Benazir Bhutto, and Bilqees Edhi. This paper also suggested very significant fact that the government and the concerned authorities must invest on women education, health and nutrition, training, safety and security, empowerment, employment and also for their shelter. 
The government of Pakistan is very serious for the progress of women but in this regard implementation of policies and strategies is very mandatory instead of paper work. Besides this government of Pakistan launched the productive plans for the welfare of women such as First Women's Bank Limited, the Agricultural Development Bank of Pakistan and Khushali Bank (these banks provide finance to rural women), the national fund for advancement of rural women, village-based family planning workers lady health workers program etc. These papers also proved that Pakistani women are playing the role very efficiently for the prosperity of country.

\section{Recommendations}

The paper find out that woman has a vital role in bringing economic prosperity regardless of the economic group and culture. We also found out that the women of Pakistan are hardworking and have the ability to contribute in the economic growth of the country. The research however suggested that that the contribution of women in economic prosperity of Pakistan is very less as discussed above. The reasons are culture of the country which doesn't allow empowerment of women. Hence, it is at first recommended that the sick mentality of the people should be corrected by bringing awareness especially in the rural areas of Pakistan where the women are deprived of rights. The women should be provided with education so that they can know about their rights and can be empowered. The women of Pakistan have the ability to contribute in earning with their men to reduce the load from men as the only bread winners. Thus it is suggested that awareness should be created by removing the misconceptions in people that the religion Islam, which is followed in the country doesn't allow women to work. It is also suggested that the quota system on employment opportunities in the corporations should be removed and all the companies should focus on equal employment opportunities so that the women can have the chance to get on good positions. In Pakistan, the education ratio of females especially in the rural areas is very low and this should be improved. The low ratio is due to the reason of poverty that parents cannot afford school fees hence the government school system should be improved so that the girls get education and know about their rights and can also contribute in business activity to bring economic prosperity in the country.

\section{References}

Duflo, Esther (2012). Women Empowerment and Economic Development, CEPR Discussion paper No. DP8734, p.1.

IMF Staff Discussion Note, (Sep, 2013). Women, Work and the Economy: Macroeconomic Gains from Gender Equity, pp 4-5. 
Gender and Development Group World Bank (April, 2003). Gender Equality Gender and the Millennium Development Goals, p.4.

Meng, Xin (1998). The Economic Position of Women in China, Clara Working Paper, No. 4, pp 11, 23.

Cinamon, Rachel, Gali, Habayib, Halah, Ziv, Margalit (2015). The Conception of Work and Higher Education among Israeli Arab Women, International Journal of Education Research, p.2.

Arar, Khalid, Husneyand Quedar, Abu-Rabia (2011). Turning Points in the Lives of Two Pioneer Arab Women Principals in Israel, Gender and Education, vol.23:4, pp.1-15.

Fatima, Goher (2010). Female Education as a Determinant of Economic Growth- (A case Study of Pakistan), International Conference on Applied Economic, - ICOAE 2010, p.167.

Toor, Imran, Ashraf (2007). Returns to Education: The Case of Fertility, Pakistan Economic and Social Review 45, pp.12-17.

Grumenfelden, Julia, (2013). Negotiating Gender Relations: Muslim Women and Formal Employment in Pakistan, Rural Development Sector. Gender, Work and Organization, vol.20:6, pp.600-606.

Besio, K. (2006). Charter and Ladders Negotiating Gender and Privilege in a Village in Northern Pakistan. An International E-journal for Critical Geographic, pp 2 \& 5.

Weiss, A., (1984). Tradition and Modernity at the Work Plan A Field Study of Women in Pharmaceutical Industry of Lahore, Women, Studies International Forum, vol.7:4, p.2.

Bushra, Aliya \& Wajiha, Nasra (2015). Assessing the Socio-Economic Determination of Women Empowerment in Pakistan, Procedia Social and Behavioral Sciences 177, pp.1-4.

Mujahid, Nooreen, Muhammad, Sulaiman D. \& Noman, M. (2013). Economic GrowthFemale Labour Force participation Nexus: An Empirical Evidence for Pakistan" Developing Country Studies, vol.3:3, pp.16-18.

Faridi, M. Zahir, Chaudhry, Imran, Sharif \& Malik, M. Shaukat (2011). Why Women are Self-Employed? Empirical Evidence from Pakistan, International Journal of Economics and Finance, vol.3:1, pp.198-199. 
234 Role of Women in Economic Development of Pakistan: A Case Study of Women Participation in Labour Force in Pakistan

Chaudhry, Imran, Sharif, Nosheen, Farhana \& Lodhi, M. Idrees (2012). Women Empowerment in Pakistan with Special References to Islamic Viewpoint: An Empirical Study, Pakistan Journal of Social Sciences (PJSS), vol.32:1, pp.171-176.

Parveen, Shahida \& Rubab, Iram, (2013). Islamic Perspective of Women's Employment, Cottage Industry Development for Rural Women of Pakistan, Al-Qalam, pp.55-57.

Pakistan Bureau of Statistics, “Labor Force Survey 2009-15”, Government of Pakistan, pp.25-26.

Begum, Razia \& Yasmeen, Ghazala (2011). Contribution of Pakistani Women in Agriculture Productivity and Constraints, vol.27:4, Sarhad J. Agric, pp.637-642.

Rashid, Yahya, \& Abdullah, Iqra, (2013). Women Empowerment in the Corporate Sector of Pakistan, Interdisciplinary Journal of Contemporary Research in Business, vol.5:5, pp.518-520.

Min, Humeza, Ali, Humeza, Ahmed, Munir \& Zafar, Muhammad, Iqbal (2009). Participation Level of Rural Women in Agricultural Activities, Pak. J. Agri. Sci, vol.46:4, pp.294-295.

Zakar, Muhammad, Zakria (2011). Strengthening Women's Political Participation and Leadership for Effective Democratic Governance in Pakistan, A Base Line Research Study, p.1.

Sadaf Mustafa is an Assistant Professor in the Department of Commerce, University of Karachi.

Dr. M. Sadiq Ali Khan is an Associate Professor in the Department of Computer Science, University of Karachi.

Ammad Zafar is M. Phil Student in the Department of Public Administration, University of Karachi. 